\title{
Physical activity levels in Portuguese high school physical education
}

European Physical Education Review 18(2) 191-204

(C) The Author(s) 2012

Reprints and permissions: sagepub.co.uk/journalsPermissions.nav DOI: $10.1177 / 1356336 \times 12440022$ epe.sagepub.com

@SAGE

\section{José Francisco Filipe Marmeleira}

Research Center in Sports Sciences, Health Sciences and Human Development, Portugal and University of Évora, Portugal

\section{Nuno Micael Carrasqueira Aldeias and Pedro Miguel dos Santos Medeira da Graça}

University of Évora, Portugal

\begin{abstract}
The main aim of this study was to evaluate the physical activity (PA) levels of high school Portuguese students during physical education (PE) and investigate the association of PA levels with students' goal orientation and intrinsic motivation. Forty-six students from three high schools participated. Heart rate telemetry and pedometry were used to assess PA and the Borg rate of perceived exertion scale was used to measure perceived exertion. Thirty PE lessons were monitored. The results indicated that high school PE lessons involve low levels of PA. Students engaged in moderate to vigorous PA (MVPA) only in about one-third (29.7 minutes) of the official PE scheduled time (90 minutes) and perceived exertion as light. In general, students seemed to be positively motivated toward PE and mainly task goal orientated. Boys felt more enjoyment/interest and perceived their competence in more positive ways than girls. The number of steps and the rate of perceived exertion were associated with levels of PA measured by heart rate telemetry. Intrinsic motivation and goal orientation were not related with MVPA.
\end{abstract}

\section{Keywords}

physical education, physical activity, intrinsic motivation, goal orientation

\section{Introduction}

There is a marked trend toward an increase in sedentary lifestyles among school-age children (Trudeau and Shephard, 2005). In fact, the decline in physical activity (PA) with age is one of the most consistent findings in PA epidemiology (Sallis, 2000), and the PA levels among young people are frequently inferior to what is recommended to promote health benefits (Cavill et al., 2001). It

\section{Corresponding author:}

José Francisco Filipe Marmeleira, Department of Sports and Health, University of Évora, Prolongamento da Rua Reguengos de Monsaraz, 14, 7000-727, Évora, Portugal

Email: jmarmel@uevora.pt 